\title{
Canadian Provincial Population Growth: Fertility, Migration, and Age Structure Effects
}

\author{
Barry Edmonston ${ }^{1}$ \\ University of Victoria \\ be@uvic.ca
}

\begin{abstract}
The effect of changes in rates of mortality, fertility, and migration depend not only on the agespecific patterns and levels of these rates, but on the age structure of the population. In order to remove the influences of the age structure and concentrate on the impact of the demographic rates themselves, a common practice is to analyze the influences of the rates for a standard age structure. This paper adapts the general approach of using a standard age structure to a stationary population equivalent (SPE) model, and analyzes current population change, using the SPE model, for provinces of Canada. Below-replacement fertility levels are only partially offset by net immigration. The SPE model evidences the decrease in the eventual provincial populations brought about by the below replacement fertility. Out-migration for some provinces to other areas of Canada accentuates their eventual population decreases.
\end{abstract}

Keywords: fertility, mortality, migration, age structure, stationary population equivalent

\section{Résumé}

Les effets des changements des taux de mortalité, fécondité, et de migration dépendent non seulement des modèles par âge et des niveaux de ces taux, mais aussi de la structure par âge de la population. Pour éliminer les influences de la structure par âge et se concentrer sur les effets des taux démographiques mêmes, une pratique courante est d'analyser les influences des taux par une structure par âge de norme. Cet article adapte l'approche générale de la structure par âge à un modèle de population stationnaire équivalente (PSE). Cet article analyse les changements de population, en utilisant le modèle de PSE, dans les provinces canadiennes. Le taux de fécondité inférieur au seuil de reproduction de la population n'est que légèrement compensé par l'immigration nette. Le modèle de PSE démontre le déclin des populations provinciales éventuelles causé par le taux de fécondité inférieur au seuil de reproduction de la population. Le taux d'émigration entre certaines provinces et reste du Canada accentue l'éventuel déclin de leurs populations.

Mots clés: fécondité, mortalité, migration, structure par âge, population stationnaire équivalente

1. Barry Edmonston is Research Professor, Department of Sociology, and Associate Director, Population Research Group, University of Victoria. An earlier version of this paper was presented at the annual meetings of the Canadian Population Society, University of British Columbia, 4-6 June 2008. 


\section{Introduction}

There is some public policy interest in affecting the settlement patterns of immigrants in Canada. This interest takes various forms. Several provinces have programs designed to encourage doctors and nurses to settle in rural and northern areas (Citizenship and Immigration Canada, 2001:16-20) that affect resident as well as new immigrant health professionals. Canadian provinces and territories also use the Provincial Nominee Program - an agreement between the federal and provincial government that allows provincial governments to nominate an applicant for an immigrant visa without having to obtain the pass mark required for a skilled worker visa - to recruit workers in demand in selected rural areas and smaller towns (Citizenship and Immigration Canada, 2008). Although not an official provincial policy of Québec, the recent report of the Commission de Consultation sur les Pratiques d'Accomodement reliées aux Differences Cultures (Bouchard and Taylor, 2008) recommended that more of the annual 45,000 immigrants arriving in Québec should settle in rural areas and regions outside of Montreal.

Although there is considerable interest in population change in provinces and especially in programs to increase growth rates in provinces and areas with declining populations, there has been a scarcity of systematic examination of the effect of fertility, mortality, and migration on provincial population change. This paper examines current levels of childbearing and several types of migration, international and interprovincial flows, in order to understand better the dynamics of provincial population change.

In prior work (Edmonston, 2006), we used stable population theory and Fisher's reproductive value to develop the concept of the stationary population equivalent (SPE), a model of population change under assumed regimes of mortality, fertility, and international migration. The advantage of the SPE model is that it incorporates age-specific schedules of immigration and emigration, while avoiding the pitfalls of some earlier approaches. In particular, the SPE model examines population change in the absence of the effect of population momentum, an effect that can present a distorted picture of long-term implications for population dynamics in many industrial populations that had significantly higher fertility in the recent past.

Previous discussion of stable and stationary population models have been limited to discussion of national populations. This paper considers subnational patterns in the SPE model for provincial populations of Canada: the effect of provincial variations in mortality, the age-sex structure of in-migrants and out-migrants, and fertility levels. A key feature of this analysis is that internal and international migration are distinguished, so that 
the results display the extent to which provincial variations in population growth depend on different migration flows.

Migration effects have several complexities: (a) migrants move both in and out of a population, (b) migration takes different forms, such as international and internal, (c) migration streams usually vary in their age and sex composition, and (d) migrants may have different fertility levels than the resident population. This paper expands on previous work with an approach for modelling the effects of migration on a hypothetical stationary population and shows the effects of internal and international migration on Canadian provincial population growth.

Canada, a country characterized by moderate to high levels of international migration into and out of the national population and below replacement fertility, currently has SPE levels that indicate long-term population decline, although positive net immigration offsets some of the decline implicit in below replacement fertility. This paper investigates the impact of migration - both internal and international - on the hypothetical future population (the SPE) of Canadian provinces.

\section{Background}

When recent changes in fertility and international migration create differences between the current age schedule and the eventual stable age structure implied by current rates, then current crude vital rates may give distorted indications of the long-run demographic consequences of current conditions. This situation is particularly appropriate for the current Canadian population, when public policy debate focuses on consequences of immigration levels - yet the eventual demographic situation is not clear from observation of current rates.

Previous solutions to this demographic situation have generally involved the stationary population model (Coale, 1972) or the stable population model (Espenshade, 1975; Espenshade and Campbell, 1977; Keyfitz, $1968 ; 1969 ; 1971 \mathrm{a} ; 1971 \mathrm{~b} ; 1977)$. Work presented in this paper on the SPE model overcomes several limitations in past work and offers a succinct quantitative framework for demographic analysis of the impact of migration on population growth.

The earliest work on this demographic situation considered intrinsic vital rates (Dublin and Lotka, 1925), along with the intrinsic rate of natural increase. Further work by Coale, Espenshade, and Keyfitz advanced substantially the generality and application of the intrinsic rate calculations. Intrinsic rate calculations offer valuable insight, but they have several lim- 
itations. First, the standard intrinsic rate procedures do not include international migration (they assume a closed population for the calculations), and are not therefore germane to questions of long-term growth of the Canadian population. Both Keyfitz (1968) and Sivamurthy (1982) showed that international migration could be included in stable population models, although there are disadvantages (described later in this paper) to their approaches. Second, the measure of size for the stable population model, the stable population equivalent (Keyfitz, 1968:57), is complicated in calculation and interpretation. Third, the stable population equivalent measure is time dependent since, if the stable population model holds, the measure will grow by the intrinsic rate of growth.

This paper uses the stationary population equivalent (SPE) model, as an alternative to earlier procedures, for the situation of analyzing the longterm consequences of vital rates and international migration. Work in this paper develops from earlier work on the U.S. population reported in Coale (1972) and Keely and Kraly (1978); on the Canadian population reported in Edmonston and Avery (1987); and on the German population reported in Edmonston (2006). In particular, this paper presents a formal model and offers analysis of Canadian provincial populations.

The stable population model assumes constant fertility and mortality rates holding indefinitely. As a result, the stable model provides measures of an unchanging, stable age structure and unchanging vital rates in order to offer a contrasting picture for interpreting the current situation. The stationary population equivalent model differs with a stationary population: mortality is assumed to remain constant, fertility is assumed to continue at the replacement level (net reproduction rate equals one), and the current age structure is maintained.

There are several advantages to the SPE approach. The SPE model provides an unambiguous single population size for interpretation, a size that holds for all years under analysis and not just the current year. The population size calculated for this proposed stationary population model is referred to as the stationary population equivalent (SPE). Comparisons of SPE's at different times or under different conditions give simple, clear measures of population size differences. Finally, changes in mortality, fertility, or migration conditions indicate changes in population size that are unaffected by momentum or peculiarities in the current age structure, two problems that pose particular troubles for standard stable population analysis.

The SPE measure could be calculated for the Canadian population annually to determine if the eventual population size would be growing or declining (independent of momentum in the current age structure). We report here results for 2001. Further, the SPE calculation provides measures 
of the proportion of change in SPE due to mortality, fertility above or below replacement, and international migration. The impact of changes in mortality can be assessed by comparing the SPE's under the different conditions. The influence of fertility can be noted by comparing the number of births assumed by the model (net reproduction rate equals one) to actual fertility. Since increased immigration makes the SPE larger, while increased emigration makes the SPE smaller, the long-run effect of international migration can also be assessed.

A key difference between other approaches and the proposed SPE measure is the manner for dealing with the effect of migration. The Keyfitz model deals with the effect of one-time migration on a stable population and does not consider continued migration. Sivamurthy's approach assumes immigrants to be a constant proportion of the total population with a fixed age structure. The approach taken by Coale, and Keely and Kraly describes migrants as a balancing of births (that is, an additional immigrant adds to the population similar to a "birth" and an additional emigrant subtracts from the population similar to a "birth prevented") and assumes migration to be constant. This approach is clearly appropriate for emigration and potentially sensible for modelling that portion of immigration generated by relatives of past immigrants. It is not clear in the long run, though, that immigration levels will be proportionately related to current population size. In the short run, at least, Canadian immigration levels are related to a numeric limit rather than as a proportion of the current population size. Our approach can incorporate the Coale, and Keely and Kraly procedures by assuming that migration changes the life table used for calculating the reproductive value of a woman and life expectancy at birth, described below. In calculations with adjusted life tables, an immigrant is a reduction of a death and an emigrant is an additional death. The Espenshade model involves a constant number and age structure of immigrants. We find it particularly useful to adapt our SPE model to handle immigration in the fashion advocated by Espenshade, although the SPE model is not limited to this particular framework for immigration. Our model reflects the numeric ceiling on international migration that might be imposed by Canada's future immigration policy.

\section{The Stationary Population Equivalent Model}

\section{Theory}

The interrelationship of age structure, fertility, mortality, and international migration can all be treated by a single theory. This section briefly develops the theory that allows us to compare the demographic impact of mortal- 
ity, fertility, immigration, and emigration changes on Canada's population growth. We begin the theory by describing the concept of Fisher's reproductive value because it provides a basis for understanding the interrelationship of fertility and mortality in a stable population; then discuss the basic idea of a stable population age distribution (including migration); and finally show how to represent the stationary population equivalent.

In work on the genetic aspects of population, Fisher (1930:27-29) proposed the useful concept of the reproductive value. He imagined that the birth of a girl was the "lending" of a life. The girl then repaid the "debt" over her life by giving birth to female offspring. Fisher's work discounts the future at the rate of interest of $r$, the intrinsic rate of natural increase for the population. The value of 1 female child, discounted back a year at an annual rate of $r$, and compounded continuously is $\mathrm{e}^{\text {-ra }}$. For a woman aged $\mathrm{x}$, her expected births during an interval a to $\mathrm{a}+\mathrm{da}$ are $\left[\mathrm{l}_{\mathrm{a}} / \mathrm{l}_{\mathrm{x}}\right] \mathrm{m}_{\mathrm{a}}$, where the woman has a probability of living from birth to age a of $l_{a}$ and the chance of bearing a daughter between a and $a+d a$ of $m_{a}$. Discounting the births, the reproductive value of a woman at age $\mathrm{x}, \mathrm{v}_{\mathrm{x}}$, is:

$$
v_{x}=\int_{x}^{\beta} e^{-r(a-x)} \frac{l_{a}}{l_{x}} m_{a} d a
$$

where $\beta$ is the ending year of childbearing. Note that $\mathrm{v}_{0}=1$ and when $\mathrm{x}>\beta$, $\mathrm{v}_{\mathrm{x}}=0$, by definition. $\mathrm{v}_{\mathrm{x}}$ represents the prospective number of female children that would be born by females present at age $\mathrm{x}$, under prevailing mortality conditions and fertility regimes, discounted at the intrinsic rate of natural increase.

Following Keyfitz's (1971a:64) exposition of Lotka's (1939: 85) stable population work, the future population at time $\mathrm{t}, \mathrm{P}_{\mathrm{t}}$, can be expressed in terms of Q ( $\mathrm{Q}$ is a constant representing the number of births at time zero of an equivalent stable population) as:

$$
P_{t}=\frac{1}{b} \cdot Q \cdot e^{r t}
$$

where $\mathrm{b}$ is the intrinsic birth rate. Next, changing the order of integration, substituting $\mathrm{v}_{\mathrm{x}}$, and noting that if $\mathrm{r}$ equals 0 , then $\mathrm{e}^{\mathrm{rt}}$ becomes 1 and $\mathrm{P}$ becomes independent of time: 


$$
P_{0}=\frac{e_{0}}{K} \int_{0}^{\beta} P_{x} v_{x} d x
$$

where $\mathrm{K}$ equals the mean age of childbearing and $\mathrm{e}_{0}$ is substituted for $\mathrm{l} / \mathrm{b} . \mathrm{P}_{0}$ is the aggregate population value, at the initial year, of the present mortality and fertility schedules, and of the current age distribution for stationary population assumptions. $\mathrm{P}_{0}$ is, hence, the stationary population equivalent (SPE) for females.

The final task is to rewrite equation (3) to express the function in terms of both sexes. Note, first of all, that the initial male population has no influence on a female-dominant calculation. Rather, for a female-dominant model, it suffices to include the sex ratio at birth and the life expectancy at birth, for both sexes. It helps to consider that $\mathrm{e}_{0} / \mathrm{K}$ is the number of generations in the population, and the number of generations in population for both sexes, $\mathrm{N}$, can be written:

$$
N=\frac{e_{0}^{f}}{K}+\frac{e_{0}^{m}}{K} \cdot \frac{1-s}{s}=\frac{1}{K}\left(e_{0}^{f}+e_{0}^{m} \cdot \frac{1-s}{s}\right)
$$

where the superscripts $\mathrm{f}$ and $\mathrm{m}$ represent females and males, respectively, and $\mathrm{s}$ is the proportion of births that are female. Finally, the stationary population equivalent (SPE) for both sexes is:

$$
S P E=N \cdot \int_{0}^{\beta} P_{x} v_{x} d x
$$

Inclusion of in-migrants and out-migrants is straightforward in equation (5). Taking into account fertility and mortality conditions for migrants, we replace the age distribution of the population under study by the age distribution of migrants to derive an SPE for each migrant group. Note that, when the model includes different fertility and mortality schedules for migrants, the model involves different $\mathrm{N}$ and $\mathrm{v}_{\mathrm{x}}$ values for in-migrants and out-migrants. For Canadian provincial populations, we distinguish six migration types, including:

- international arrivals, 
- international departures,

- interprovincial arrivals who are Canada-born residents (Canadian citizens at birth),

- interprovincial departures who are Canada-born residents,

- interprovincial arrivals who are immigrants (not Canadian citizens at birth), and

- interprovincial departures who are immigrants.

The next section describes data for these migration types.

The overall SPE for a provincial or subnational population, including migrants, equals seven SPE-type calculations, one for the initial population, two for international migrants, two for interprovincial migrants who are Canada-born residents, and two for interprovincial migrants who are foreign-born residents.

The basic SPE analysis can be extended in several ways in order to understand the interrelationship of migration and fertility. There are three possible situations in which combinations of births and international migration affect the stationary population equivalent model in interesting ways. First, the model can be used to calculate replacement-level fertility in the absence of international migration - this is referred to later as replacement-level births. Second, given current fertility levels, the model provides the basis for calculating replacement-level migration - this is called replacement-level migration in a later section. Finally, the model can be used to calculate the fertility level needed for population replacement in the presence of current international migration levels - this is referred to later as fill-the-gap births. Appendix A describes each of these three situations and provides computing formulas.

\section{Data Requirements and Methods}

There are several data requirements for calculating the stationary population equivalent measures. The SPE calculation requires male and female mortality rates (using the person-years column, $\mathrm{L}_{\mathrm{x}}$, of the life table), female fertility rates (called $F_{x}$ ), the female population by age (called $P_{x}$ ) and three constants: the proportion of births that are female (called $S$ ), and life expectancy at birth for males and females (called $\mathrm{e}_{0}{ }^{\mathrm{m}}$ and $\mathrm{e}_{0}{ }^{\mathrm{f}}$ ). For each of the six migration types, the calculation requires data on males and females by age, male and female mortality rates, and female fertility rates. 
Appendix A provides computational formulas for the mean age of childbearing, $\mathrm{K}$, and the reproductive value of a woman by age, $\mathrm{v}_{\mathrm{x}}$. Knowing the population by age, $\mathrm{P}_{\mathrm{i}, \mathrm{x}}$, the SPE calculation for each province is calculated as:

$$
S P E=N \cdot \sum_{i=1}^{7} \sum_{x=1}^{45} P_{i, x} v_{i, x}
$$

where i represents the seven component groups (initial or resident population, international migrants, and interprovincial migrants by nativity) for the final computation of the stationary population equivalent. All baseline population data for this paper are for the 2001 calendar year.

The stationary population equivalent model for subnational populations requires information about fertility, mortality, internal migration, and international migration. The fertility schedule affects the calculation of the reproductive value, $\mathrm{v}_{\mathrm{x}}$, and the number of generations in the stationary population, $\mathrm{N}$, through its determination of the mean length of a generation. Fertility also appears in the proportion of births that are female, S.

The mortality schedule influences the reproductive value of the population, as well as affecting the number of generations in the population. Finally, the in-migration and out-migration schedules alter the reproductive value calculation because in-migration affects the "birth" of a new individual - albeit not necessarily at age 0 - and out-migration acts as the "death" of an existing person.

The primary source for data on the age and sex of the resident population and the age and sex composition of the six migration flows is the 2001 public use census microdata files released by Statistics Canada. We use these files because they provide the required data for the SPE analysis described above. There are other possible data sources for some of the required data. For example, Statistics Canada releases population estimates for Canada and its provinces and territories that have an adjustment for census undercount. Also, Canada Immigration and Citizenship provides annual data on the age and sex of immigrants and their initial destination. This paper relies on census microdata files because they provide the required data for migration flow that do not exist in Statistics Canada's population estimates or Canada Immigration and Citizenship files.

Population by age and sex

The observed population data, by age and sex, are for mid-May 2001 and are taken from the 2001 public use census microdata files. 


\section{Fertility}

Provincial age-specific fertility rates are taken from Statistics Canada (2003). The age-specific fertility rates for the resident population use the reported number of births by age of mother for each province. The sex ratio at birth is taken to be the observed sex ratio of births of the provinces. The sex ratio at birth has a trivial impact on the results and the sex ratio could be set to the national average of 1.053 with modest impact on the provincial results.

For the fertility rates for the migrant groups, it was necessary to develop special procedures. We lack birth registration for migrant types that would allow us to make direct fertility calculations. As an indirect estimate, 1991 census microdata files were used to calculate the number of children ever born for five-year age groups of women, 20-39 years of age, for the resident population and six migrant groups for each province. The average for children ever born was calculated for women 20-39 years of age from the four observed five-year age groups. The average was calculated in order to obtain an overall indicator of childbearing levels for the six migrant groups compared to the resident population. Next, we calculated the ratio of childbearing for each migrant type to the childbearing of the resident population. Finally, these ratios were multiplied by the provincial age-specific fertility rates in 2001 to yield an estimate of the age-specific fertility rates for each migration group. Because there are no census data on children ever born for international departures, we assume that the age-specific fertility rates for international departures are the same as international arrivals. Appendix Table B-3 displays estimates for the total fertility rates for each migration type for each province.

\section{Mortality}

We calculate 2001 life tables using data on deaths by age and sex for the 2000-2002 period, taken from Statistics Canada (2006). Age-specific mortality rates were tabulated by sex, and the probability of dying between $\mathrm{x}$ and $x+n,{ }_{n} q_{x}$ were estimated by procedures developed by Chiang (1968). We used the ${ }_{n} a_{x}$ values published in Namboodiri and Suchindran (1987:26) for constructing the 2001 Canadian life tables by sex. We assume that mortality levels for migration groups are the same as the resident provincial populations.

\section{Migration}

The migration groups are defined as the 2001 census population who reported that they had an international or interprovincial move between 1996 2001. For each group, the estimate of 2001 arrivals (or departures) is made by dividing the number of arrivals (or departures) during 1996-2001 by five 
and assuming that the age distribution is 2.5 years younger than reported age in 2001. Statistics Canada makes annual estimates by age and sex, for each province, of interprovincial migrants; however, these estimates do not distinguish the nativity of migrants, which is required for this analysis. The six migration groups are defined as follows:

1. International arrivals are persons who reported that they lived outside Canada in 1996 and are not Canada-born citizens.

2. International departures are not enumerated in the 2001 census of Canada. An estimate of international departures is calculated as the annual average number of persons leaving each province, by year, for 1996-2001, as reported in Statistics Canada's Annual Demographic Estimates (1996, 1997, 1998, 1999, 2000, and 2001). We assume that the sex distribution of international departures is the same as international arrivals and that the age distribution is five years older than international arrivals. The age assumption is premised on the notion that most international departures are international arrivals that decide not to remain in Canada and are, on average, five years older.

3. Interprovincial arrivals who are Canada-born citizens report that they lived in another province in 1996, moved to their current provincial residence between 1996-2001, and are Canadian citizens at birth.

4. Interprovincial departures who are Canada-born citizens report that they lived in another province in 1996, and moved from their prior province between 1996-2001, and are Canadian citizens at birth.

5. Interprovincial arrivals who are immigrants report that they lived in another province in 1996, moved to their current provincial residence between 1996-2001, and are not Canadian citizens at birth.

6. Interprovincial departures who are immigrants report that they lived in another province in 1996, and moved from their prior province between 1996-2001, and are not Canadian citizens at birth.

Appendix Table B-2 presents data on the average number of migrants, by type and province, used for the 2001 stationary population equivalent analysis.

\section{Results}

The stationary population equivalent (SPE) model is particularly attractive for analysis of Canada's provincial population growth for several reasons. 
First, current Canadian provincial population policy discussion often focuses on the annual volume of international immigration and its long-term consequences on population growth. Although emigration is obviously of interest to policy makers, it is less susceptible to policy measures than immigration. Second, provincial fertility levels in Canada have been relatively unchanging at close to or below replacement levels for more than two decades. Fertility levels, of course, vary somewhat by province. Below replacement fertility means, if continued, that the provincial populations will eventually suffer negative rates of natural increase. Any possible provincial population will, given negative rates of natural increase, derive solely from the offsetting contributions of positive net internal and international migration. Finally, as documented later in this paper, there is modest momentum in the current Canadian age structure. With no net in-migration and below replacement fertility, provincial populations will begin to decline in the near future. As a result, the present observed levels of provincial population growth are poor indicators of long-term growth. And, given the modest momentum built into the current age structure, projections of growth in the near future are deficient measures of the interrelated dynamics of fertility, mortality, and internal and international migration.

\section{Usefulness of the SPE Model}

In order to evaluate better the effect of internal and international migration on the Canadian provincial populations, we use the SPE model as an indication of population size and rate of change. This allows the analysis to balance fertility and mortality with estimates of in-migration and out-migration to assess the effect of each of these factors on the long-term population size of Canada. Our specific interest is to estimate the amount of decline in the stationary population equivalent implied by various levels of these rates, and to analyze the contribution of in-migration necessary to prevent a decline in Canada's provincial populations.

The results reported here complement the most recent population projections of Statistics Canada (Bélanger et al., 2005), which show 2005-2031 population trends under different assumptions about the levels and patterns of age-specific rates of fertility, mortality, and migration.

The SPE model offers a different method for understanding the future Canadian provincial populations under various demographic alternatives. This paper, therefore, contrasts the use of population projections with an explicit population model for addressing debate on the future implications of immigration and emigration on national social and economic structure. 


\section{Main Results}

Table B-1 displays basic fertility and mortality data for Canadian provinces in 2001. The first two columns show estimates of life expectancy, by sex, using provincial reports of deaths by age. Fertility, as measured by the net reproduction rate, is substantially below replacement for all provinces except the combined population of Yukon and Northwest Territories and Nunavut. The mean length of a generation varies slightly by province, with the youngest childbearing in the combined population of Yukon, Northwest Territories, and Nunavut and the oldest in Ontario. The number of female generations per female birth varies inversely with the mean length of a generation, but depends also on life expectancy. Saskatchewan has the greatest number of generations (5.89) and Ontario has the lowest (5.52). The number of generations per female birth for Canada overall equals 5.62 in 2001, reflecting a mean length of a generation of 29.0 years and the life expectancies, by sex, shown earlier. The number, 5.62, means each additional female birth adds 5.62 persons to the population: herself, her son and daughter, her grandson and granddaughter, and 0.62 other descendants, for instance all alive at the same time in the eventual stationary population. Provincial values for the number of generations per female birth range around the Canadian average of 5.62, with Ontario and British Columbia being noticeably below the national level and Saskatchewan and New Brunswick above the national level.

Using the age structure of in-migrants and out-migrants, for both internal and international migrants, and following the procedures outlined above, the stationary population equivalent analysis for each province can described.

Table 1 shows the current 2001 and SPE populations for each province. The SPE population value indicates the provincial population size that would be reached, assuming replacement level fertility and the 2001 levels of mortality and migration. In other words, the SPE value would result if the current ratio of migration to population were to continue indefinitely, and if fertility were raised to yield replacement level fertility. A stationary population under these conditions would be older and larger - with an SPE of 31.7 million for Canada - than the current population. Another view of the SPE population value is that it is a "pure" measure of population momentum: it indicates the future growth potential for each province given the population increase inherent in the current age distribution, including the age distribution of migrants. Overall, the Canadian population would increase modestly by $6 \%$. Most provinces are close to the national level, although the combined population of Yukon, Northwest Territories, and Nunavut displays a 
Table 1. Current and Stationary Population Equivalent (SPE) Size and Population Momentum for Canada, Provinces, and Territories, 2001

\begin{tabular}{lrrr}
\hline \multirow{2}{*}{\multicolumn{1}{c}{ Province or Territory }} & \multicolumn{2}{c}{ Population } & Momentum: Ratio \\
\cline { 2 - 3 } of SPE to Current
\end{tabular}

Notes: The analysis for Canada, its provinces, and territories, is done separately. The sum of figures for provinces and territories may differ from the total reported for Canada. Some of the difference is due to rounding error. Most of the difference in the SPE analysis is due to the fact that there is heterogenity in provincial and territorial population dynamics and the overall average for the national population will differ from the sum of results for provinces and territories.

particularly high level of population momentum, with growth of $32 \%$. The current age structure of Quebec portends negligible momentum, with no future population growth due to its current age structure.

\section{Detailed Results}

We turn now to a detailed accounting of how current fertility and migration contribute to provincial SPE values. This accounting can be made for either actual numbers or for values relative to the total provincial SPE population. Both the actual numbers and the relative values have useful interpretations, and both are discussed below.

Table 2 shows the contribution of births to the provincial SPE calculations. Except for the combined population of Yukon, Northwest Territories, and Nunavut, fertility levels are below the number required to replace provincial populations. As a result, current fertility gives a negative contribution to the 2001 SPE values (shown in column 5). Relative to the total SPE value, fertility levels for the combined population of Yukon, Northwest Territories, and Nunavut increase its 2001 SPE value each year by about 900 . The fertility levels in Newfoundland reduce 2001 SPE values by more than $3 \%$ for each year current fertility rates continue. Current fertility rates decrease the SPE values by 2.0-2.9\% in Nova Scotia, New Brunswick, Quebec, Ontario, and British Columbia. The influence of current fertility rates is 
Table 2. Contribution of Births to Stationary Population Equivalent (SPE) Size and Population Momentum for Canada, Provinces, and Territories, 2001

\begin{tabular}{|c|c|c|c|c|c|c|}
\hline \multirow[b]{2}{*}{$\begin{array}{l}\text { Province or } \\
\text { Territory }\end{array}$} & \multicolumn{4}{|c|}{ Births } & \multicolumn{2}{|c|}{$\begin{array}{c}\text { Change in SPE } \\
\text { due to Births }\end{array}$} \\
\hline & Observed & Replacement & Difference & $\begin{array}{l}\text { Relative } \\
\text { Difference }\end{array}$ & Number & Relative \\
\hline Canada & 318,917 & 432,616 & $-113,699$ & $-35.7 \%$ & $-311,127$ & $-1.0 \%$ \\
\hline $\begin{array}{l}\text { Newfoundland and } \\
\text { Labrador }\end{array}$ & 4,604 & 7,384 & $-2,780$ & $-60.4 \%$ & $-7,717$ & $-1.5 \%$ \\
\hline $\begin{array}{l}\text { Prince Edward } \\
\text { Island }\end{array}$ & 1,357 & 1,832 & -475 & $-35.0 \%$ & $-1,315$ & $-0.9 \%$ \\
\hline Nova Scotia & 8,598 & 12,747 & $-4,149$ & $-48.3 \%$ & $-11,418$ & $-1.2 \%$ \\
\hline New Brunswick & 6,887 & 10,167 & $-3,279$ & $-47.6 \%$ & $-9,355$ & $-1.3 \%$ \\
\hline Quebec & 71,453 & 99,662 & $-28,209$ & $-39.5 \%$ & $-77,808$ & $-1.1 \%$ \\
\hline Ontario & 124,694 & 169,465 & $-44,772$ & $-35.9 \%$ & $-120,278$ & $-1.0 \%$ \\
\hline Manitoba & 13,495 & 15,499 & $-2,004$ & $-14.9 \%$ & $-5,621$ & -0.55 \\
\hline Saskatchewan & 11,881 & 13,108 & $-1,227$ & -1.35 & $-3,523$ & $-0.3 \%$ \\
\hline Alberta & 36,436 & 45,485 & $-9,049$ & $-24.8 \%$ & $-25,149$ & $-0.7 \%$ \\
\hline British Columbia & 37,999 & 56,567 & $-18,568$ & $-48.9 \%$ & $-50,581$ & $-1.2 \%$ \\
\hline $\begin{array}{l}\text { Yukon, Northwest } \\
\text { Territories, Nunavut }\end{array}$ & 1,672 & 1,518 & 154 & $9.2 \%$ & 426 & $.03 \%$ \\
\hline \multicolumn{7}{|c|}{$\begin{array}{l}\text { Notes: The analysis for Canada, its provinces, and territories is done separately. The sum of figures for provinces } \\
\text { and territories may differ from the total reported for Canada. Some of the difference is due to rounding error. Most of } \\
\text { the difference in the SPE analysis is due to the fact that there is heterogeneity in provincial and territorial population } \\
\text { dynamics and the overall average for the national population will differ from the sum of results for provinces and } \\
\text { territories. }\end{array}$} \\
\hline
\end{tabular}

diminished in Prince Edward Island, Manitoba, Saskatchewan, and Alberta, where the SPE values are decreased by less than $2 \%$.

Table 3 presents the contribution of migration, by type, to the SPE calculation, while Table 5 gives similar information for provincial migration (international and interprovincial). These data are unique to SPE-type analysis, because they disentangle the complex population effects of in and out provincial migration flows. Especially because provincial migration flows vary by age and sex, and by fertility levels (as represented by the $\mathrm{v}_{\mathrm{x}}$ values), the SPE analysis permits a useful summary of the population growth effect of these flows.

Overall, Canada has a net international migration that contributes about 265,211 to the national SPE value. All provinces experienced net gains from international migration. In terms of the relative contribution of net international migration, Ontario and British Columbia have increases of 1.0 percent or more in their SPE value.

In absolute terms, Ontario and Alberta demonstrate particularly large contributions of net interprovincial migration to their SPE values. British Columbia had a high level of interprovincial in-migration that is offset by 
Table 3. Contribution of International and Interprovincial Migration to Stationary Population Equivalent (SPE) Size for Canada, Provinces, and Territories, 2001

Panel A. Numerical Effect on Stationary Population Equivalent

\begin{tabular}{|c|c|c|c|c|c|c|c|c|c|}
\hline \multirow[b]{2}{*}{ Province or Territory } & \multicolumn{3}{|c|}{ Overall Migration } & \multicolumn{3}{|c|}{ International Migration } & \multicolumn{3}{|c|}{$\begin{array}{c}\text { Interprovincial } \\
\text { Migration }\end{array}$} \\
\hline & 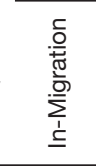 & 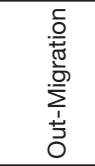 & 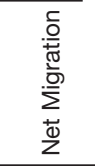 & 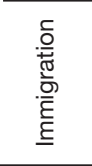 & 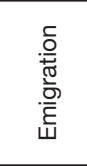 & 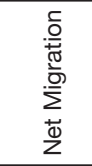 & 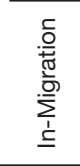 & 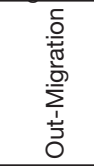 & 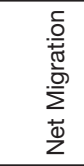 \\
\hline Canada & 359,751 & $-94,540$ & 265,211 & 359,751 & $-94,540$ & 265,211 & 0 & 0 & 0 \\
\hline $\begin{array}{l}\text { Newfoundland and } \\
\text { Labrador }\end{array}$ & 6,302 & $-17,389$ & $-11,087$ & 759 & -356 & 403 & 5,543 & $-17,033$ & $-11,490$ \\
\hline Prince Edward Island & 3,449 & $-2,777$ & 672 & 365 & -101 & 264 & 3,084 & $-2,676$ & 408 \\
\hline Nova Scotia & 21,736 & $-19,677$ & 2,059 & 3,024 & $-1,371$ & 1,653 & 18,712 & $-18,305$ & 406 \\
\hline New Brunswick & 12,327 & $-33,413$ & $-21,086$ & 1,366 & -705 & 661 & 10,960 & $-32,708$ & $-21,748$ \\
\hline Quebec & 75,670 & $-58,383$ & 17,287 & 53,975 & $-17,215$ & 36,759 & 21,696 & $-41,168$ & $-19,472$ \\
\hline Ontario & 277,306 & $-111,238$ & 166,068 & 189,418 & $-40,999$ & 148,420 & 87,888 & $-70,239$ & 17,649 \\
\hline Manitoba & 25,210 & $-24,815$ & 395 & 7,524 & $-2,468$ & 5,5056 & 17,686 & $-22,347$ & $-4,661$ \\
\hline Saskatchewan & 20,595 & $-27,181$ & $-6,586$ & 2,965 & $-1,820$ & 1,145 & 17,630 & $-25,361$ & $-7,731$ \\
\hline Alberta & 122,049 & $-54,418$ & 67,631 & 27,603 & $-10,221$ & 17,382 & 94,446 & $-44,197$ & 50,249 \\
\hline British Columbia & 117,890 & $-82,372$ & 35,518 & 66,630 & $-17,643$ & 48,716 & 51,530 & $-64,729$ & $-13,199$ \\
\hline $\begin{array}{l}\text { Yukon, Northwest } \\
\text { Territories, Nunavut }\end{array}$ & 4,516 & $-6,975$ & -2459 & 323 & -159 & 164 & 4,192 & $-6,816$ & $-2,624$ \\
\hline
\end{tabular}

Panel B. Relative Contribution on Stationary Population Equivalent, Percent

\begin{tabular}{|c|c|c|c|c|c|c|c|c|c|}
\hline \multirow[b]{2}{*}{ Province or Territory } & \multicolumn{3}{|c|}{ Overall Migration } & \multicolumn{3}{|c|}{ International Migration } & \multicolumn{3}{|c|}{$\begin{array}{c}\text { Interprovincial } \\
\text { Migration }\end{array}$} \\
\hline & 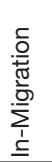 & 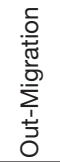 & 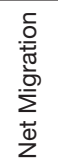 & 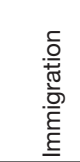 & 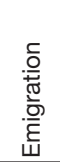 & 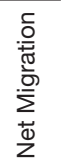 & 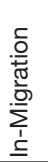 & 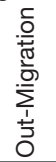 & 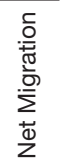 \\
\hline Canada & 1.1 & -0.3 & 0.8 & 1.1 & -0.3 & 0.8 & 0.0 & 0.0 & 0.0 \\
\hline Newfoundland and Labrador & 1.2 & -3.4 & -2.1 & 0.1 & -0.1 & 0.1 & 1.1 & -3.3 & -2.2 \\
\hline Prince Edward Island & 2.4 & -1.9 & 0.5 & 0.3 & -0.1 & 0.2 & 2.1 & -1.8 & 0.3 \\
\hline Nova Scotia & 2.4 & -2.1 & 0.2 & 0.3 & -0.1 & 0.2 & 2.0 & -2.0 & 0.0 \\
\hline New Brunswick & 1.7 & -4.5 & -2.9 & 0.2 & -0.1 & 0.1 & 1.5 & -4.5 & -3.0 \\
\hline Quebec & 1.0 & -0.8 & 0.2 & 0.7 & -0.2 & 0.5 & 0.3 & -0.6 & -0.3 \\
\hline Ontario & 2.3 & -0.9 & 1.4 & 1.5 & -0.3 & 1.2 & 0.7 & -0.6 & 0.1 \\
\hline Manitoba & 2.1 & -2.0 & 0.0 & 0.6 & -0.2 & 0.4 & 1.4 & -1.8 & -0.4 \\
\hline Saskatchewan & 1.9 & -2.5 & -0.6 & 0.3 & -0.2 & 0.1 & 1.6 & -2.3 & -0.7 \\
\hline Alberta & 3.6 & -1.6 & 2.0 & 0.8 & -0.3 & 0.5 & 2.8 & -1.3 & 1.5 \\
\hline British Columbia & 2.9 & -2.0 & 0.9 & 1.6 & -0.4 & 1.2 & 1.3 & -1.6 & -0.3 \\
\hline $\begin{array}{l}\text { Yukon, Northwest Territories, } \\
\text { Nunavut }\end{array}$ & 3.7 & -5.7 & -2.0 & 0.3 & -0.1 & 0.1 & 3.4 & -5.6 & -2.1 \\
\hline
\end{tabular}

even higher levels of interprovincial out-migration. The effect of net interprovincial migration (shown in column 9) indicates strong relative gains for Alberta, moderate net gains for Prince Edward Island and Ontario, negligible change for Nova Scotia, moderate net losses for Quebec and British Columbia, and sizeable net losses for Newfoundland and Labrador and the combined population of Yukon, Northwest Territories, and Nunavut. 
Combining international and internal migration (columns 1-3), Alberta and Ontario witnessed net gains of $1 \%$ or more in their SPE values. Ontario experienced the biggest absolute gains from the combined contributions of interprovincial and international migration, increasing its SPE value by 166,000 each year such migration levels continue, with most of its gain deriving from net international migration. Alberta witnessed the highest relative gain, with a $2 \%$ increase in its SPE value or 68,000 increase each year its current migration levels continue. British Columbia is of some interest: its substantial net gain from international migration was more than offset by net losses from internal migration.

Of particular interest are interprovincial migration flows by nativity. Although all provinces benefit from net international migration, some international arrivals eventually move from their initial province of settlement. Table 4 reveals the different interprovincial movements of Canada-born and immigrant residents, using the same format as Table 3.

Columns 4-6 of Table 4 show substantial net interprovincial migration effects of Canada-born residents for two provinces: Alberta and Ontario. With an SPE value increase of 47,000, Alberta's SPE value was increased by $1.4 \%$ by net interprovincial migration of Canada-born residents. Prince Edward Island and Nova Scotia experienced positive net interprovincial migration of Canada-born residents, which raised their SPE values slightly. All other provinces had negative net interprovincial migration of Canada-born residents. Several areas were particularly affected by net interprovincial out-migration of Canada-born residents: Newfoundland and Labrador, New Brunswick, and the combined population of Yukon, Northwest Territories, and Nunavut experienced large negative relative effects of $2.0 \%$, which significantly reduce their SPE population value each year such migration levels continue.

Foreign-born residents had net positive interprovincial migration in only three provinces: Ontario, Alberta, and British Columbia. All other provinces experienced net interprovincial out-migration of their immigrant residents. As a result, the positive net contribution of international migration is often offset by the departure of immigrant residents. Overall, the relative contribution of net interprovincial migration of immigrant residents, as shown in column 9, is modest.

Table 5 summarizes numerical and relative contributions to the SPE calculation for births, international migration, and interprovincial migration. Overall, substantial fertility deficits outweigh Canada's current net migration. All provinces except Alberta and Ontario follow this overall conclusion. Only Alberta and Ontario, with substantial positive net migration contributions enjoyed a positive total contribution to the SPE value. If 
conditions do not change, Alberta's SPE value will increase $1.2 \%$, or 42,000 and Ontario's SPE value will gain $0.4 \%$, or 48,000, each year current fertility, mortality, and migration conditions prevail. All other provinces display negative contributions to their SPE values, although the underlying demo-

Table 4. Contribution of Interprovincial Migration by Nativity, to Stationary Population Equivalent (SPE) Size for Canada, Provinces, and Territories, 2001

\begin{tabular}{|c|c|c|c|c|c|c|c|c|c|}
\hline \multicolumn{10}{|c|}{ Panel A. Numerical Effect on Stationary Population Equivalent } \\
\hline \multirow[b]{2}{*}{ Province or Territory } & \multicolumn{3}{|c|}{$\begin{array}{l}\text { Interprovincial } \\
\text { Migration for Canada-born } \\
\text { and Foreign-born Combined }\end{array}$} & \multicolumn{3}{|c|}{$\begin{array}{c}\text { Interprovincial } \\
\text { Migration of Canada- } \\
\text { born }\end{array}$} & \multicolumn{3}{|c|}{$\begin{array}{l}\text { Interprovincial } \\
\text { Migration of Foreign- } \\
\text { born }\end{array}$} \\
\hline & 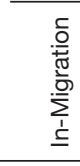 & 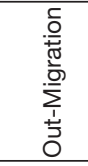 & 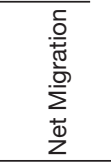 & 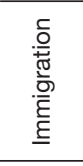 & 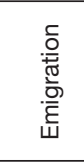 & 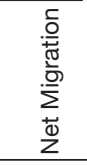 & 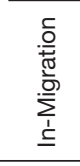 & 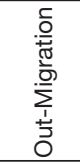 & 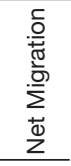 \\
\hline Canada & 0 & 0 & 0 & 0 & 0 & 0 & 0 & 0 & 0 \\
\hline $\begin{array}{l}\text { Newfoundland and } \\
\text { Labrador }\end{array}$ & 5,543 & $-17,033$ & $-11,490$ & 5,322 & $-16,531$ & $-11,209$ & 221 & -502 & -281 \\
\hline Prince Edward Island & 3,084 & $-2,676$ & 408 & 2,997 & $-2,525$ & 472 & 87 & -151 & -65 \\
\hline Nova Scotia & 18,712 & $-18,305$ & 406 & 17,730 & $-17,080$ & 650 & 982 & $-1,226$ & -244 \\
\hline New Brunswick & 10,960 & $-32,708$ & $-21,748$ & 10,525 & $-32,114$ & $-21,589$ & 435 & -594 & -158 \\
\hline Quebec & 21,696 & $-41,168$ & $-19,472$ & 18,985 & $-31,638$ & $-12,653$ & 2,710 & $-9,530$ & $-6,820$ \\
\hline Ontario & 87,888 & $-70,239$ & 17,649 & 71,321 & $-59,784$ & 11,537 & 16,567 & $-10,455$ & 6,111 \\
\hline Manitoba & 17,686 & $-22,347$ & $-4,661$ & 16,298 & $-20,002$ & $-3,704$ & 1,388 & $-2,345$ & -956 \\
\hline Saskatchewan & 17,630 & $-25,361$ & $-7,731$ & 16,513 & $-23,514$ & $-7,001$ & 1,116 & $-1,847$ & -731 \\
\hline Alberta & 94,446 & $-44,197$ & 50,249 & 86,166 & $-39,020$ & 47,146 & 8,280 & $-5,177$ & 3,104 \\
\hline British Columbia & 51,530 & $-64,729$ & $-13,199$ & 42,528 & $-56,752$ & $-14,225$ & 9,003 & $-7,977$ & 1,026 \\
\hline $\begin{array}{l}\text { Yukon, Northwest } \\
\text { Territories, Nunavut }\end{array}$ & 4,192 & $-6,816$ & $-2,624$ & 3,840 & $-6,329$ & $-2,489$ & 352 & -487 & -135 \\
\hline
\end{tabular}

Panel B. Relative Contribution on Stationary Population Equivalent, Percent

\begin{tabular}{|c|c|c|c|c|c|c|c|c|c|}
\hline \multirow[b]{2}{*}{ Province or Territory } & \multicolumn{3}{|c|}{$\begin{array}{l}\text { Interprovincial Migration } \\
\text { for Canada-born and } \\
\text { Foreign-born Combined }\end{array}$} & \multicolumn{3}{|c|}{$\begin{array}{c}\text { Interprovincial } \\
\text { Migration of Canada- } \\
\text { born }\end{array}$} & \multicolumn{3}{|c|}{$\begin{array}{c}\text { Interprovincial } \\
\text { Migration of Foreign- } \\
\text { born }\end{array}$} \\
\hline & 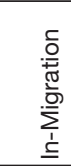 & 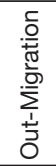 & 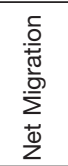 & 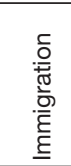 & 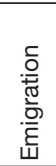 & 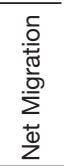 & 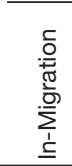 & 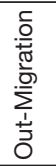 & 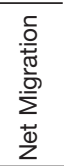 \\
\hline Canada & 0.0 & 0.0 & 0.0 & 0.0 & 0.0 & 0.0 & 0.0 & 0.0 & 0.0 \\
\hline $\begin{array}{l}\text { Newfoundland and } \\
\text { Labrador }\end{array}$ & 1.1 & -3.3 & -2.2 & 1.0 & -3.2 & -2.2 & 0.0 & -0.1 & -0.1 \\
\hline Prince Edward Island & 2.1 & -1.8 & 0.3 & 2.1 & -1.7 & 0.3 & 0.1 & -0.1 & 0.0 \\
\hline Nova Scotia & 2.0 & -2.0 & 0.0 & 1.9 & -1.9 & 0.1 & 0.1 & -0.1 & 0.0 \\
\hline New Brunswick & 1.5 & -4.5 & -3.0 & 1.4 & -4.4 & -2.9 & 0.1 & -0.1 & 0.0 \\
\hline Quebec & 0.3 & -0.6 & -0.3 & 0.3 & -0.4 & -0.2 & 0.0 & -0.1 & -0.1 \\
\hline Ontario & 0.7 & -0.6 & 0.1 & 0.6 & -0.5 & 0.1 & 0.1 & -0.1 & 0.0 \\
\hline Manitoba & 1.4 & -1.8 & -0.4 & 1.3 & -1.6 & -0.3 & 0.1 & -0.2 & -0.1 \\
\hline Saskatchewan & 1.6 & -2.3 & 0.7 & 1.5 & -2.1 & -0.6 & 0.1 & -0.2 & -0.1 \\
\hline Alberta & 2.8 & -1.3 & 1.5 & 2.5 & -1.1 & 1.4 & 0.2 & -0.2 & 0.1 \\
\hline British Columbia & 1.3 & -1.6 & -0.3 & 1.0 & -1.4 & -0.4 & 0.2 & -0.2 & 0.0 \\
\hline $\begin{array}{l}\text { Yukon, Northwest } \\
\text { Territories, Nunavut }\end{array}$ & 3.4 & -5.6 & -2.1 & 3.1 & -5.2 & -2.0 & 0.3 & -0.4 & -0.1 \\
\hline
\end{tabular}


graphic processes show distinctive provincial patterns. Canada's provinces fall into several categories:

1. Newfoundland and New Brunswick have low fertility, modest net international migration, and heavy net interprovincial losses. Both provinces evidence reductions of about $4 \%$ in their 2001 SPE levels. Over the five-year 1996-2001 period, their eventual stationary population value decreased by about one-fifth.

2. Prince Edward Island, Nova Scotia, Quebec, Manitoba, and Saskatchewan have net positive international migration, negative or negligible net interprovincial migration, and below replacement fertility. In each province, overall net in-migration fails to counterbalance low fertil-

Table 5. Contribution to Stationary Population Equivalent (SPE) Size for Births, International Migration, and Interprovincial Migration, for Canada, Provinces, and Territories, 2001

\begin{tabular}{lrrrrr}
\hline \hline \multicolumn{3}{c}{ Panel A. Numerical Effect on Stationary Population Equivalent } \\
\hline & & & \multicolumn{4}{c}{ Migration } \\
\cline { 4 - 6 } Province or Territory & Total & Births & \multicolumn{1}{c}{ Total } & International & Interprovincial \\
\hline Canada & $-45,916$ & $-311,127$ & 265,211 & 265,211 & 0 \\
Newfoundland and Labrador & $-18,804$ & $-7,717$ & $-11,087$ & 403 & $-11,490$ \\
Prince Edward Island & -644 & $-1,315$ & 672 & 264 & 408 \\
Nova Scotia & $-9,359$ & $-11,418$ & 2,059 & 1,653 & 406 \\
New Brunswick & $-30,441$ & $-9,355$ & $-21,086$ & 661 & $-21,748$ \\
Quebec & $-60,521$ & $-77,808$ & 17,287 & 36,759 & $-19,472$ \\
Ontario & 45,791 & $-120,278$ & 166,068 & 148,420 & 17,649 \\
Manitoba & $-5,226$ & $-5,621$ & 395 & 5,056 & $-4,661$ \\
Saskatchewan & $-10,109$ & $-3,523$ & $-6,586$ & 1,145 & $-7,731$ \\
Alberta & 42,483 & $-25,149$ & 67,631 & 17,382 & 50,249 \\
British Columbia & $-15,063$ & $-50,581$ & 35,518 & 48,716 & $-13,199$ \\
Yukon, Northwest Territories, & $-2,034$ & 426 & $-2,459$ & 164 & $-2,624$ \\
Nunavut & & & & &
\end{tabular}

\begin{tabular}{lccccc}
\hline \multicolumn{3}{c}{ Panel B. Relative Contribution on Stationary Population Equivalent, Percent } \\
\hline \multirow{2}{*}{ Province or Territory } & Total & Births & Total & International & Interprovincial \\
\cline { 5 - 6 } Canada & -0.1 & -1.0 & 0.8 & 0.8 & 0.0 \\
Newfoundland and Labrador & -3.6 & -1.5 & -2.1 & 0.1 & -2.2 \\
Prince Edward Island & -0.4 & -0.9 & 0.5 & 0.2 & 0.3 \\
Nova Scotia & -1.0 & -1.2 & 0.2 & 0.2 & 0.0 \\
New Brunswick & -4.1 & -1.3 & -2.9 & 0.1 & -3.0 \\
Quebec & -0.8 & -1.1 & 0.2 & 0.5 & -0.3 \\
Ontario & 0.4 & -1.0 & 1.4 & 1.2 & 0.1 \\
Manitoba & -0.4 & -0.5 & 0.0 & 0.4 & -0.4 \\
Saskatchewan & -0.9 & -0.3 & -0.6 & 0.1 & -0.7 \\
Alberta & 1.2 & -0.7 & 2.0 & 0.5 & 1.5 \\
British Columbia & -0.4 & -1.2 & 0.9 & 1.2 & -0.3 \\
Yukon, Northwest Territories, & 1.7 & 0.3 & -2.0 & 0.1 & -2.1 \\
Nunavut & &
\end{tabular}

Note: The analysis for Canada, its provinces, and territories is done separately. The sum of figures for provinces and territories may differ from the total reported for Canada. Some of the difference is due to rounding error. Most of the difference in the SPE analysis is due to the fact that there is heterogeneity in provincial and territorial population dynamics and the over all average for the national population will differ from the sum of results for provinces and territories. 
ity. As a result, there were moderate declines in their SPE population values.

3. Ontario and British Columbia experienced very high levels of net international migration. Ontario had positive net interprovincial migration while British Columbia had negative net interprovincial migration. Both had similar patterns of net interprovincial migration of immigrant residents, however, and had sizeable contributions from overall net migration to their SPE values. Below replacement fertility counterbalanced their net positive migration contributions and, as a result, Ontario witnessed moderate positive gains and British Columba experienced modest negative changes in their SPE population value.

4. The combined population of Yukon, Northwest Territories, and Nunavut is the only area in Canada with above replacement fertility. Net interprovincial migration losses, however, produced declines in their SPE value.

5. Alberta experienced positive net international migration as well as large positive net interprovincial migration, which overcame its below replacement fertility to produce a substantial gain in its SPE population value of 42,000 , or $1.2 \%$.

Taking all provinces together and noting their total relative contributions to their SPE (see column 1 in Panel B of Table 5), only Alberta and Ontario increased their SPE values. Prince Edward Island, Quebec, Manitoba, Saskatchewan, and British Columbia experienced decreases in their SPE value of less than 1\%. Newfoundland and Labrador, Nova Scotia, New Brunswick, and the combined population of Yukon, Northwest Territories, and Nunavut, with below replacement fertility and inadequate net in-migration, saw their 2001 SPE values decline by $1 \%$ or more.

\section{Replacement-level Immigration and Fertility}

This section discusses replacement-level immigration and fertility. We can make these calculations using the SPE model (see Appendix A for discussion of computing formulas).

Given the current fertility levels, how many immigrants, assuming the present age structure of migrants, are needed to maintain a stationary population for each province? For example, 219,000 immigrants are required annually to maintain the current SPE of 31.7 million for Canada (see Table 6). This level of immigration is $13 \%$ higher than current immigration levels but somewhat below Statistics Canada's "medium" immigration assumption of 234,200 for 2000-2004 (Bélanger et al., 2005:27). 
Although slightly higher levels of immigration could offset current low fertility levels for the national population, Table 6 indicates that different levels of in-migration - whether from international or interprovincial sources - are required as replacement in-migration for provincial populations. Newfoundland and Labrador requires more than three times current in-migration and New Brunswick needs more than two times current inmigration. Other provinces require additional in-migration to offset current low fertility levels, with needs ranging from about 10-80\% increases. Only Alberta and Ontario could maintain their SPE population levels with fewer in-migrants.

Assuming either zero net migration for Canada or each province or, alternatively, assuming current net migration, how many births are required to maintain a stationary population? Answers to both questions are shown in Table 7. The calculation for the assumption of zero net migration is straightforward because a stationary population that is closed to migration requires a net reproduction rate of 1.00 . In this case, if there were zero net migration, the number of births in Canada would need to increase from 320,000 to 433,000 each year, an increase of 114,000 or $36 \%$. Even larger relative fertility increases would be required in Newfoundland and Labrador (an increase of $60 \%$ ) and British Columbia (a gain of $49 \%$ ) because of their currently low fertility levels. The combined populations of Yukon and Northwest Territories and Nunavut have above replacement-level fertility and could maintain

\section{Table 6. Current and Replacement In-Migration* for Canada,}

\section{Provinces, and Territories, 2001}

\begin{tabular}{lcrrr}
\hline \hline & & \multicolumn{3}{c}{ Replacement In-Migration } \\
\cline { 3 - 5 } Province or Territory & Current In-Migration & Number & Difference & Percent Change \\
\hline Canada & 193,950 & 218,704 & 24,755 & 12.8 \\
Newfoundland and Labrador & 3,812 & 15,188 & 11,376 & 298.4 \\
Prince Edward Island & 1,800 & 2,136 & 336 & 18.7 \\
Nova Scotia & 12,795 & 18,304 & 5,509 & 43.1 \\
New Brunswick & 7,291 & 25,298 & 18,006 & 247.0 \\
Quebec & 39,284 & 70,704 & 31,420 & 80.0 \\
Ontario & 150,847 & 125,938 & $-24,909$ & -16.5 \\
Manitoba & 12,580 & 15,187 & 2,608 & 20.7 \\
Saskatchewan & 10,493 & 15,644 & 5,151 & 49.1 \\
Alberta & 64,126 & 41,805 & $-22,321$ & -34.8 \\
British Columbia & 70,132 & 79,093 & 8,961 & 12.8 \\
Yukon, Northwest Territories, & 2,522 & 3,657 & 1,136 & 45.0 \\
Nunavut & & & \\
\hline${ }^{*}$ Replacement in-migration is the number of in-migrants - given current fertility and out-migration - that are needed \\
to maintain the stationary population equivalent size at a constant level. \\
Note: The analysis for Canada, its provinces, and territories is done separately. The sum of figures for provinces and \\
territories may differ from the total reported for Canada. Some of the difference is due to rounding error. Most of the \\
difference in the SPE analysis is due to the fact that there is heterogeneity in provincial and territorial population dynam- \\
ics and the over all average for the national population will differ from the sum of results for provinces and territories. \\
\end{tabular}


Table 7. Current and Replacement Births* for Canada, Provinces, and Territories, 2001

\begin{tabular}{|c|c|c|c|c|c|c|c|}
\hline \multirow[b]{2}{*}{ Province or Territory } & \multirow[b]{2}{*}{$\begin{array}{l}\text { Current } \\
\text { Births }\end{array}$} & \multicolumn{3}{|c|}{$\begin{array}{c}\text { Replacement Births Assuming } \\
\text { Zero Net Migration }\end{array}$} & \multicolumn{3}{|c|}{$\begin{array}{l}\text { Replacement Births Assuming } \\
\text { Current Net Migration }\end{array}$} \\
\hline & & Number & Difference & $\begin{array}{l}\text { Percent } \\
\text { Change } \\
\end{array}$ & Number & Difference & $\begin{array}{l}\text { Percent } \\
\text { Change } \\
\end{array}$ \\
\hline Canada & 318,917 & 432,616 & 113,699 & 35.7 & 335,697 & 16,780 & 5.3 \\
\hline $\begin{array}{l}\text { Newfoundland and } \\
\text { Labrador }\end{array}$ & 4,604 & 7,384 & 2,780 & 60.4 & 11,379 & 6,775 & 147.2 \\
\hline Prince Edward Island & 1,357 & 1,832 & 475 & 35.0 & 1,590 & 232 & 17.1 \\
\hline Nova Scotia & 8,598 & 12,747 & 4,149 & 48.3 & 11,999 & 3,401 & 39.6 \\
\hline New Brunswick & 6,887 & 10,167 & 3,279 & 47.6 & 17,558 & 10,671 & 154.9 \\
\hline Quebec & 71,453 & 99,662 & 28,209 & 39.5 & 93,395 & 21,941 & 30.7 \\
\hline Ontario & 124,694 & 169,465 & 44,772 & 35.9 & 107,649 & $-17,045$ & -13.7 \\
\hline Manitoba & 13,495 & 15,499 & 2,004 & 14.9 & 15,358 & 1,863 & 13.8 \\
\hline Saskatchewan & 11,881 & 13,108 & 1,227 & 10.3 & 15,401 & 3,521 & 29.6 \\
\hline Alberta & 36,436 & 45,485 & 9,049 & 24.8 & 21,150 & $-15,286$ & -42.0 \\
\hline $\begin{array}{l}\text { British } \\
\text { Columbia }\end{array}$ & 37,999 & 56,567 & 18,568 & 48.9 & 43,529 & 5,530 & 14.6 \\
\hline $\begin{array}{l}\text { Yukon, Northwest } \\
\text { Territories, Nunavut }\end{array}$ & 1,672 & 1,518 & -154 & -9.2 & 2,408 & 736 & 44.0 \\
\hline \multicolumn{8}{|c|}{$\begin{array}{l}\text { "Replacement births are the number of births - assuming either no net migration or current migration - that are needed to } \\
\text { maintain the stationary population equivalent size at a constant level. } \\
\text { Note: The analysis for Canada, its provinces, and territories is done separately. The sum of figures for provinces and territories } \\
\text { may differ from the total reported for Canada. Some of the difference is due to rounding error. Most of the difference in the SPE } \\
\text { analysis is due to the fact that there is heterogeneity in provincial and territorial population dynamics and the over all average for } \\
\text { the national population will differ from the sum of results for provinces and territories. }\end{array}$} \\
\hline
\end{tabular}

a stationary population - given zero net migration - with slightly lower fertility. All other provinces require sizeable increases in fertility in order to maintain stationary populations in the absence of positive in-migration.

As demonstrated earlier, current net migration offsets below replacement-level fertility for some provinces. Given current net migration - including both international and interprovincial sources - how many births are required to sustain a stationary population? Because of positive net immigration, Canada's population could achieve a stationary population with current net immigration levels and fertility increases of 5\%. Exceptionally large fertility increases would be required in Newfoundland and Labrador $(147 \%)$ and New Brunswick (155\%) in order to offset sizeable net out-migration. As before, Alberta is an exception because it could maintain a stationary population with even lower fertility levels. In other provinces, fertility increases of $13-44 \%$ are required under current net migration conditions.

\section{Conclusions}

The various population models considered here provide results consistent with formal analyses and Statistics Canada's population projections (see 
Ryder, 1997 and Beaujot, 2003 for related discussion of the effect of immigration on Canada's population change). The stationary population equivalent (SPE) model stresses, in particular, that at given mortality and fertility, each province requires more in-migrants to maintain their stationary population. As long as the net reproduction rate remains below replacement, as it has for some time for most provinces, 2001 levels of net provincial inmigration are inadequate to counterbalance eventual population decline. In order to maintain current SPE levels, potential provincial in-migrants could stem from internal sources, although this would merely worsen the situation for other provinces. With about 57,000 emigrants (the 2001 level), Canada requires about 219,000 immigrants annually to maintain the current SPE of 31.7 million. This is about $13 \%$ higher than the current immigration levels. National increases in immigration would, of course, affect provincial immigration levels.

Higher fertility levels during the post-World War II baby boom period produced a population with more youth and fewer elderly in the 1980s than would exist in a stable population with vital rates of the 1980s. Lower fertility rates during the past twenty years, however, have reversed this situation. At present, there are about the same proportion of youth, more adults in the working years, and fewer elderly than would be expected in the stable population associated with current vital rates. As a result, for the first time, the Canadian population has relatively modest momentum inherent in its age structure. If current low fertility levels persist, the age structure with increasing age and momentum will become negative - a condition in which Canada's population will resemble many European populations. When negative population momentum exists, it means that the population will continue to decline for some time even if replacement-level fertility were achieved.

These results should be provocative in light of current public debate about Canada's immigration policies and Canada's important international role as a recipient of immigrant and refugee populations. For example, greatly increased numbers of immigrants can be accommodated within the demographic realm of a Canadian stationary population - there is room for about 25,000 additional annual immigrants, without exceeding the longterm SPE goal of 31.7 million.

Two key conclusions about Canadian provincial growth emerge from this study. First, the momentum of population growth does not vary greatly among Canadian provinces. Most provinces have age distributions (for the initial population and for the migrants) that imply an additional $0-15 \%$ growth, given the assumptions of the SPE model. The combined population of Yukon, Northwest Territories, and Nunavut, however, has the highest 
inherent momentum, with an SPE population 32\% greater than the current population. Unlike earlier periods - such as the 1970s, when there was considerable momentum inherent in the age structure of Canada's provincial population - future provincial growth will quickly slacken without higher fertility levels or increased in-migration.

Second, all provinces except the combined population of Yukon, Northwest Territories, and Nunavut have a large net deficit in 2001 SPE value because of below replacement-level fertility. Each year that current fertility levels prevail, the long-term stationary population of Canada decreases by about $1 \%$, or 311,000 . Similar relative declines in the stationary population value exist for all provinces, with noticeable large relative decreases due to low fertility in Newfoundland and Labrador, Nova Scotia, New Brunswick, Quebec, and British Columbia.

Migration offsets low fertility levels in several provinces. Net positive international migration is largest in Ontario and British Columbia. International migration contributes smaller net positive amounts in Quebec and Alberta. Interprovincial migration makes an exceptionally strong net positive contribution to Alberta's stationary population level. In fact, net interprovincial migration, coupled with modest net international migration, insures that Alberta's stationary population level increases each year by about 42,000 , or $1.2 \%$. Prince Edward Island, Nova Scotia, and Ontario had negligible net positive interprovincial migration contributions to their stationary population levels. The remaining provinces experienced net negative interprovincial migration - especially Newfoundland and Labrador and New Brunswick - accentuating stationary population equivalent decreases due to low fertility.

As this analysis reveals, the contribution of interprovincial migration of immigrants and Canada-born residents are not always similar. First, net interprovincial migration of immigrants has a relatively minor influence on population change in all provinces. Although there are a substantial number of immigrants leaving Quebec and Manitoba, and arriving in Ontario, Alberta, and British Columbia, the overall effect on provincial stationary population levels is minor. In all provinces, the effect of the interprovincial migration of immigrants on stationary population equivalent levels is between -0.1 and $+0.1 \%$. Second, it is variation in the interprovincial migration of Canada-born residents that has the most pronounced effect on stationary population levels. The effect is greatly positive for Alberta and strongly negative for Newfoundland and Labrador, New Brunswick, and the combined population of Yukon, Northwest Territories, and Nunavut - reflecting large volume interprovincial flows and their fertility and age distribution characteristics. 
From a policy perspective, interprovincial migration poses a zerosum game for provincial decision-makers. Every extra person who can be recruited or induced to move to their province is, in fact, an additional resident lost to another province. If all provinces were to encourage more interprovincial migration, they would compete with each other and not address the overall national population situation. Noncompetitive provincial policies that wish to increase population growth, or diminish population declines, are limited to two basic approaches: increasing the number of births or increasing the number of immigrants.

Aside from policy implications, these results illustrate that the SPE model provides meaningful and flexible methods for evaluating provincial population dynamics. Analyzing the effect of migration on population change has proved to be a complicated topic for demographers, and even more difficult to interpret for policymakers and the public. This paper shows how the SPE model can be adapted to subnational population analysis, including the analysis of interprovincial and international migration. The SPE-approach offers a relatively direct computational tool as well as specific quantitative indicators for measuring and interpreting the effect of fertility, mortality, and migration on population growth.

\section{References}

Beaujot, Roderic. 2003. "Effect of immigration on the Canadian population: Replacement migration?” Discussion Paper no. 03-03. Population Studies Centre, University of Western Ontario.

Bélanger, Alain, Laurent Martel, and Éric Caron-Malenfant. 2005. Population Projections for Canada, Provinces and Territories. Ottawa: Statistics Canada, Catalogue no. 91-520XIE.

Bouchard, Gérard and Charles Taylor. 2008. Building the Future: A Time for Reconciliation. Québec: Commission de Consultation sur les Pratiques d'Accomodement reliées aux Differences Cultures.

Chiang, Chin Long. 1968. Introduction to Stochastic Processes in Biostatistics. New York: John Wiley \& Sons.

Citizenship and Immigration Canada. 2001. Towards a More Balanced Geographic Distribution of Immigrants. Ottawa: Citizenship and Immigration Canada.

2008. "Provincial nominees." Citizenship and Immigration Canada website: www.cic. gc.ca/English/immigrate/provincial/index.asp. Accessed 16 June 2008.

Coale, Ansley J. 1972. “Alternative paths to stationary population.” Pp. 589-604 in C.F. Westoff and R. Parke, eds., Demographic and Social Aspects of Population Growth. Volume 1 of Commission Research Reports, U.S. Commission on Population Growth and the American Future. Washington, D.C.: Government Printing Office. 
Dublin, Louis I. and Alfred J. Lotka. 1925. "On the true rate of natural increase." Journal of the American Statistical Association 20:305-339.

Edmonston, Barry. 2006. "Population dynamics in Germany: The role of immigration and population momentum.” Population Research and Policy Review 25:513-545.

Edmonston, Barry and Roger C. Avery. 1987. "The impact of international migration on Canada's population growth: An application of the stationary population equivalent model." In F. Trovato and P. Krishnan, eds., Contributions to Demography: Methodological and Substantive Essays in Honour of Dr. Karol J. Krótki. Edmonton, AB: Population Research Laboratory, University of Alberta.

Espenshade, Thomas J. 1975. "The stable decomposition of the rate of natural increase." Theoretical Population Biology 8 (1):91-115.

Espenshade, Thomas J. and Graham Campbell. 1977. "The stable equivalent population, age composition and Fisher's reproductive value function." Demography 14 (February):87-96.

Fisher, Ronald A. 1930. The Genetical Theory of Natural Selection. Oxford: Oxford University Press.

Keely, Charles B. and Ellen P. Kraly. 1978. "Recent net alien immigration to the United States: Its impact on population growth and native fertility." Demography 15:267-283.

Keyfitz, Nathan. 1968. Introduction to the Mathematics of Population. Reading, MA: Addison-Wesley.

1969. "Age distribution and the stable equivalent." Demography 6 (May):261-269.

1971a. "Migration as means of population control." Population Studies 25(1):63-72.

1971b. "On the momentum of population growth." Demography 8 (February):71-80.

1977. Applied Mathematical Demography. New York: John Wiley \& Sons.

Lotka, Alfred J. 1939. Analyze Demoqraphique avec application particuliere a l'Espece Humaine. Paris.

Namboodiri, Krishnan and C.M. Suchindran. 1987. Life Table Techniques and Their Applications. Orlando, FL: Academic Press.

Ryder, Norman. 1997. "Migration and population replacement." Canadian Studies in Population 24(1):1-26.

Sivamurthy, M. 1982. Growth and Structure of Human population in the Presence of Migration. London: Academic Press.

Statistics Canada. 1996. Annual Demographic Estimates: Canada, Provinces and Territories. Ottawa: Statistics Canada, Catalogue no. 91-215-XWE.

1997. Annual Demographic Estimates: Canada, Provinces and Territories. Ottawa: Statistics Canada, Catalogue no. 91-215-XWE.

1998. Annual Demographic Estimates: Canada, Provinces and Territories. Ottawa: Statistics Canada, Catalogue no. 91-215-XWE.

1999. Annual Demographic Estimates: Canada, Provinces and Territories. Ottawa: Statistics Canada, Catalogue no. 91-215-XWE.

2000. Annual Demographic Estimates: Canada, Provinces and Territories. Ottawa: Statistics Canada, Catalogue no. 91-215-XWE.

2001. Annual Demographic Estimates: Canada, Provinces and Territories. Ottawa: Statistics Canada, Catalogue no. 91-215-XWE. 
2003. Births, 2001. Ottawa: Statistics Canada, Catalogue no. 84-F0210-XPB.

2006. Life Tables, Canada, Provinces and Territories: 2000 to 2002. Ottawa: Statistics Canada, Catalogue no. 84-537-XIE. 


\section{Appendix A. \\ Computing Formulas for Stationary Population Equivalent Analysis}

\section{Calculation Formulas}

Knowing life table $\mathrm{L}_{\mathrm{x}}$ values and age-specific fertility rates, $\mathrm{F}_{\mathrm{x}}$, the mean age of childbearing, $\mathrm{K}$, is:

$$
K=\frac{\sum_{x=15}^{45}(x+2.5) \cdot L_{x} \cdot F_{x}}{\sum_{x=15}^{45} L_{x} \cdot F_{x}}
$$

The reproductive value of a woman at age $\mathrm{x}$, for a stationary population, is calculated with the following formula:

$$
v_{x}=5 \bullet \frac{F_{x}}{2 \cdot N R R}+\sum_{y=x+5}^{45} 5 \bullet \frac{L_{y}}{L_{x}} \cdot \frac{F_{y}}{N R R}
$$

Note that one might consider an improved estimate of $\mathrm{F}_{\mathrm{x}} /(2 \bullet \mathrm{NRR})$ with $\left[F_{x} /(2 \bullet N R R)\right]\left[L_{x+5} / L_{x}\right]^{1 / 4}$ to take mortality changes by age into account. But the refinement in the mortality term that would result, in the maximum change for these Canadian data, is an adjustment of 0.9969 . We include the mortality adjustment in this analysis but it makes a negligible difference compared to the results that would be obtained using equation (A-2). The mortality adjustment, however, should be included in analysis of high mortality populations.

Knowing the population by age, $\mathrm{P}_{\mathrm{x}}$, the SPE calculation yields:

$$
\operatorname{SPE}(P)=N \cdot \sum_{x=1}^{45} P_{x} v_{x}
$$

for the final computation of the stationary population equivalent. For the stationary population equivalent calculations for migrants, $\mathrm{P}_{\mathrm{x}}$ uses migrants by age and sex and the $\mathrm{v}_{\mathrm{x}}$ for migrants. 


\section{Calculating Alternative Fertility and Migration Effects}

We can study the effect of change for three SPE-type calculations. The SPE does not change, year to year, as long as the model conditions remain the same: constant mortality, replacement level fertility, and no migration. Any change in the demographic conditions, however, produces a corresponding change in the SPE. For example, each birth below replacement decreases the SPE by N. Immigrants add to and emigrants subtract from the SPE by the amounts SPE(in-migrants) or SPE(out-migrants) in equation (6). The overall effect of international migration at time $t$, called $\mathrm{OE}(\mathrm{t})$, can be written as:

$$
O E(t)=N \cdot\left[B_{t}-B_{t}^{r}+\int_{0}^{\beta} I_{t, x} v_{x} d x-\int_{0}^{\beta} E_{t, x} v_{x} d x\right]
$$

where $\mathrm{B}(\mathrm{t})$ is the actual number of female births in year $\mathrm{t}, \mathrm{B}(\mathrm{t})$ is the number of female births needed for replacement (at a net reproduction rate equal to one) for year $t$, and $\mathrm{I}_{\mathrm{t}, \mathrm{x}}$ and $\mathrm{E}_{\mathrm{t}, \mathrm{x}}$ are the number of immigrants and emigrants by age $\mathrm{x}$ in year $\mathrm{t}$, respectively.

It is useful to consider three possible situations in which combinations of changes in births and international migration might affect the overall stationary population equivalent model. The first situation is where replacement-level fertility prevails in the absence of international migration. The second involves replacement-level immigration in the presence of observed below replacement births. The third situation pertains to increases in current fertility levels to "fill-the-gap" in the presence of current immigration. Various other calculations, based on equation (A-4), might be made to examine population dynamics in other situations.

\section{Replacement-level births}

If there were zero international migration, the number of replacement-level births is:

$$
B_{t}^{r}=\int_{\alpha}^{\beta} \frac{P_{x} m_{x}}{N R R} d x=B_{t} \bullet \frac{1}{N R R}
$$

or, more simply, the number of replacement-level births equals the observed number of births times $1 / \mathrm{NRR}$.

\section{Replacement-level immigration}

Given current fertility levels, how many immigrants are required annually to maintain the stationary population equivalent? Replacement-level im- 
migration requires that the overall effect of fertility and international migration on the stationary population equivalent be zero. If current fertility and emigration levels prevail, the number of required replacement-level immigrants, $\mathrm{I}^{\mathrm{r}}$, is:

$$
I^{r}=\frac{N \cdot \int_{0}^{\beta} P_{x} v_{x} d x-N \cdot \int_{0}^{\beta} E_{x} v_{x} d x}{N \cdot \int_{0}^{\beta} I_{x} v_{x} d x / I}
$$

where $P_{x}$ is the female population by age, $E_{x}$ is the emigrant population by age, $I_{x}$ is the immigrant population by age, and $I$. is the current total number of immigrants.

\section{Fill-the-gap births}

A third possible situation involves the question of how much current fertility would need to increase to maintain the stationary population equivalent in the presence of current international migration levels. Recalling equation (A-4) for the overall effect of international migration on the SPE calculation, we set equation (A-4) to zero in order to derive the "fill-the-gap" number of births, $\mathrm{B}^{\mathrm{fg}}$ :

$$
B_{t}^{f g}=B_{t}^{r}-\frac{\int_{0}^{\beta} I_{t, x} v_{x} d x-\int_{0}^{\beta} E_{t, x} v_{x} d x}{N}
$$




\section{Appendix B. \\ Input Data for Stationary Population Equivalent Analysis for Canadian Provinces}

Table B1. Basic Input Data for Stationary Population Equivalent Analysis: Life Expectancy at Birth, By Sex; NNR; K; and N for Canada, Provinces, and Territories, 2001

\begin{tabular}{|c|c|c|c|c|c|}
\hline \multirow[b]{2}{*}{$\begin{array}{l}\text { Province or } \\
\text { Territory }\end{array}$} & \multicolumn{2}{|c|}{$\begin{array}{c}\text { Life Expectancy } \\
\text { at Birth, e(0) }\end{array}$} & \multirow[b]{2}{*}{$\begin{array}{l}\text { Net Reproduction } \\
\text { Rate, NRR }\end{array}$} & \multirow[b]{2}{*}{$\begin{array}{l}\text { Mean Length of } \\
\text { a Generation, K }\end{array}$} & \multirow[b]{2}{*}{$\begin{array}{l}\text { Number of } \\
\text { Generations per } \\
\text { Female Birth, N }\end{array}$} \\
\hline & Female & Male & & & \\
\hline Canada & 82.01 & 76.91 & 0.74 & 29.02 & 5.62 \\
\hline $\begin{array}{l}\text { Newfoundland } \\
\text { and Labrador }\end{array}$ & 81.00 & 75.16 & 0.62 & 28.10 & 5.70 \\
\hline $\begin{array}{l}\text { Prince Edward } \\
\text { Island }\end{array}$ & 81.74 & 75.47 & 0.74 & 28.34 & 5.69 \\
\hline Nova Scotia & 81.31 & 76.08 & 0.67 & 28.57 & 5.65 \\
\hline New Brunswick & 81.84 & 76.24 & 0.68 & 27.68 & 5.86 \\
\hline Quebec & 81.98 & 76.38 & 0.72 & 28.68 & 5.66 \\
\hline Ontario & 82.02 & 77.36 & 0.74 & 29.64 & 5.52 \\
\hline Manitoba & 81.19 & 75.66 & 0.87 & 27.94 & 5.76 \\
\hline Saskatchewan & 82.09 & 76.26 & 0.91 & 27.55 & 5.89 \\
\hline Alberta & 82.08 & 77.03 & 0.80 & 28.60 & 5.71 \\
\hline $\begin{array}{l}\text { British } \\
\text { Columbia }\end{array}$ & 82.83 & 78.07 & 0.67 & 29.51 & 5.59 \\
\hline $\begin{array}{l}\text { Yukon, Northwest } \\
\text { Territories, } \\
\text { Nunavut }\end{array}$ & 76.87 & 71.72 & 1.10 & 26.87 & 5.67 \\
\hline
\end{tabular}


Table B2. Basic Input Data for Stationary Population Equivalent Analysis: International and Interprovincial Migrants for Canada, Provinces, and Territories, 2001

\begin{tabular}{|c|c|c|c|c|c|c|c|c|c|}
\hline \multicolumn{10}{|c|}{ Panel A. Total Migration and International Migration } \\
\hline \multirow{2}{*}{\multicolumn{2}{|c|}{ Province or Territory }} & \multicolumn{4}{|c|}{ Total Migration } & \multicolumn{4}{|c|}{ International Migration } \\
\hline & & ry Arrivals & \multicolumn{2}{|c|}{ s Departures } & Net & \multicolumn{2}{|c|}{ Immigrants } & Emigrants & Net \\
\hline \multicolumn{2}{|c|}{ Canada } & 193,950 & \multicolumn{2}{|c|}{57,121} & 136,828 & \multicolumn{2}{|c|}{193,950} & 57,121 & 136,828 \\
\hline \multicolumn{2}{|c|}{$\begin{array}{l}\text { Newfoundland and } \\
\text { Labrador }\end{array}$} & 3,812 & \multicolumn{2}{|c|}{10,258} & $-6,446$ & \multicolumn{2}{|c|}{535} & 276 & 259 \\
\hline \multirow{2}{*}{\multicolumn{2}{|c|}{$\begin{array}{l}\text { Prince Edward Island } \\
\text { Nova Scotia }\end{array}$}} & 1,800 & \multicolumn{2}{|c|}{1,680} & 120 & \multicolumn{2}{|c|}{247} & 75 & 172 \\
\hline & & 12,795 & & 1,202 & \multicolumn{2}{|c|}{1,857} & 929 & 928 \\
\hline \multicolumn{2}{|c|}{ New Brunswick } & 7,291 & \multicolumn{2}{|c|}{8,645} & $-1,354$ & \multicolumn{2}{|c|}{808} & 472 & 335 \\
\hline \multicolumn{2}{|c|}{ Quebec } & 39,284 & & 5,602 & 26,902 & & 9,836 & 17,067 \\
\hline \multicolumn{2}{|l|}{ Ontario } & 150,847 & 6 & 4 & 87,543 & 102,53 & & 24,791 & 77,742 \\
\hline Manitoba & & 12,580 & 13,2 & & -655 & 3,823 & & 1,404 & 2,418 \\
\hline Saskatchewar & & 10,493 & 14,6 & 692 & $-4,199$ & 1,807 & & 1,228 & 578 \\
\hline Alberta & & 64,126 & 30,8 & 823 & 33,302 & 15,440 & & 6,392 & 9,048 \\
\hline British Columb & hia & 70,132 & 47,1 & 157 & 22,975 & 39,79 & & 11,606 & 28,185 \\
\hline $\begin{array}{l}\text { Yukon, Northv } \\
\text { Territories, Nu }\end{array}$ & unest & 2,522 & & 785 & $-1,263$ & 207 & & 112 & 95 \\
\hline & & Pan & B. In & ov & vincial Mig & gration & & & \\
\hline & & Total & & & Canada-borr & & & Foreign-bor & \\
\hline $\begin{array}{c}\text { Province or } \\
\text { Territory }\end{array}$ & Arrivals & Departures & Net & Arrivals & s Departures & Net & Arrivals & s Departures & Net \\
\hline Canada & 0 & 0 & 0 & 0 & 0 & 0 & 0 & 0 & 0 \\
\hline $\begin{array}{l}\text { Newfoundl } \\
\text { and Labrac }\end{array}$ & 3,277 & 9,982 & $-6,705$ & 3,099 & 9,627 & $-6,528$ & 178 & 355 & -177 \\
\hline $\begin{array}{l}\text { Prince Edward } \\
\text { Island }\end{array}$ & 1,553 & 1,605 & -52 & 1,486 & 1,479 & 7 & 67 & 126 & -58 \\
\hline Nova Scotia & 10,938 & 10,664 & 273 & 10,155 & 9,782 & 372 & 783 & 882 & -99 \\
\hline $\begin{array}{l}\text { New } \\
\text { Brunswick }\end{array}$ & 6,484 & 8,172 & $-1,689$ & 6,187 & 7,758 & $-1,570$ & 296 & 415 & -118 \\
\hline Quebec & 12,382 & 23,847 & $-11,465$ & 10,672 & 17,899 & $-7,227$ & 1,710 & 5,948 & $-4,238$ \\
\hline Ontario & 48,314 & 38,513 & 9,801 & 38,225 & 32,292 & 5,933 & 10,089 & 6,221 & 3,868 \\
\hline Manitoba & 8,757 & 11,830 & $-3,073$ & 7,876 & 10,203 & $-2,327$ & 881 & 1,627 & -746 \\
\hline $\begin{array}{l}\text { Saskatch- } \\
\text { ewan }\end{array}$ & 8,687 & 13,464 & $-4,777$ & 8,016 & 12,208 & $-4,192$ & 671 & 1,256 & -585 \\
\hline Alberta & 48,686 & 24,432 & 24,254 & 43,858 & 20,953 & 22,905 & 4,828 & 3,478 & 1,349 \\
\hline $\begin{array}{l}\text { British } \\
\text { Columbia } \\
\text { Yukon, }\end{array}$ & 30,341 & 35,551 & $-5,210$ & 24,262 & 30,431 & $-6,170$ & 6,080 & 5,120 & 960 \\
\hline $\begin{array}{l}\text { Northwest } \\
\text { Territories, } \\
\text { Nunavut }\end{array}$ & 2,315 & 3,673 & $-1,358$ & 2,138 & 3,341 & $-1,202$ & 177 & 332 & -156 \\
\hline
\end{tabular}


Table B3. Basic Input Data for Stationary Population Equivalent Analysis: Total Fertility Rate by Migration Type for Canada, Provinces, and Territories, Average Annual Number, 1996-2001

\begin{tabular}{|c|c|c|c|c|c|c|c|}
\hline \multirow[b]{3}{*}{$\begin{array}{c}\text { Province or } \\
\text { Territory }\end{array}$} & \multirow[b]{3}{*}{ Residents } & \multirow{2}{*}{\multicolumn{2}{|c|}{ International Migrants }} & \multicolumn{4}{|c|}{ Interprovincial Migrants } \\
\hline & & & & \multicolumn{2}{|c|}{ Canada-born } & \multicolumn{2}{|c|}{ Foreign-born } \\
\hline & & Immigrants & Emigrants & Arrivals & Departures & Arrivals & Departures \\
\hline Canada & 1.53 & 1.43 & 1.43 & $-^{a}$ & a & $--^{a}$ & $-^{a}$ \\
\hline $\begin{array}{l}\text { Newfoundland } \\
\text { and Labrador }\end{array}$ & 1.30 & 0.75 & 0.75 & 1.24 & 1.09 & 1.23 & 1.29 \\
\hline $\begin{array}{l}\text { Prince Edward } \\
\text { Island }\end{array}$ & 1.53 & 1.01 & 1.01 & 1.80 & 0.99 & 1.38 & 1.00 \\
\hline Nova Scotia & 1.40 & 1.11 & 1.11 & 1.26 & 1.21 & 1.13 & 0.95 \\
\hline New Brunswick & 1.41 & 1.28 & 1.28 & 1.25 & 1.16 & 1.34 & 1.31 \\
\hline Quebec & 1.49 & 1.60 & 1.60 & 1.24 & 1.27 & 1.41 & 1.43 \\
\hline Ontario & 1.53 & 1.43 & 1.43 & 1.36 & 1.39 & 1.51 & 1.70 \\
\hline Manitoba & 1.81 & 1.54 & 1.54 & 1.72 & 1.53 & 1.68 & 1.59 \\
\hline Saskatchewan & 1.89 & 1.03 & 1.03 & 1.77 & 1.38 & 1.95 & 1.20 \\
\hline Alberta & 1.67 & 1.31 & 1.31 & 1.55 & 1.49 & 1.88 & 1.49 \\
\hline British Columbia & 1.39 & 1.10 & 1.10 & 1.28 & 1.46 & 1.36 & 1.41 \\
\hline $\begin{array}{l}\text { Yukon, North- } \\
\text { west Territories, } \\
\text { Nunavut }\end{array}$ & 2.31 & 0.93 & 0.93 & 1.45 & 2.02 & 2.12 & 2.05 \\
\hline
\end{tabular}

a. not applicable 
